\title{
EVALUASI SISTEM INFORMASI PENJUALAN \\ PADA PT ARORI JAYA
}

\author{
Anderes Gui ${ }^{1}$; Maryanie²; Melvin Octorian³; Nurhadi'; William ${ }^{5}$ \\ 1, 2, 3, 4, 5 Jurusan Komputerisasi Akuntansi, Fakultas Ilmu Komputer, Universitas Bina Nusantara, \\ Jln. K.H. Syahdan No.9, Palmerah, Jakarta Barat 11480 \\ anderesgui@binus.edu
}

\begin{abstract}
The purpose of this study was to determine the level of internal control at PT Arori Jay a and provided recommendation to the weaknesses found. The method used is the method of interview, check list, observation, and documentation study. The results of the evaluation system sale information found weaknesses of each control, where there are weaknesses that allow the potential risks that may occur as well as the recommendations as necessary remedial action. The conclusion is based on the evaluation results have been obtained on credit sales information system controls at the company, still need improvement. With the internal control system of better information, it is expected the company to ensure protecting data and information from every threat that may arise.
\end{abstract}

Keywords: evaluation, credit sales information system

\begin{abstract}
ABSTRAK
Tujuan penelitian ini adalah untuk mengetahui tingkat pengendalian internal pada PT Arori Jaya dan memberikan rekomendasi untuk kelemahan-kelemahan yang ditemukan. Metode penelitian yang digunakan adalah metode wawancara, check list, observasi, dan studi dokumentasi. Hasil dari evaluasi sistem informasi penjualan ditemukan kelemahan dari masing-masing pengendalian, di mana kelemahan yang ada memungkinkan adanya potensi risiko yang dapat terjadi serta diperlukan adanya rekomendasi sebagai tindakan perbaikan. Kesimpulan adalah berdasarkan hasil evaluasi yang telah diperoleh pada pengendalian sistem informasi penjualan kredit pada perusahaan, masih perlunya perbaikan. Dengan adanya internal control sistem informasi yang lebih baik, diharapkan perusahaan dapat menjamin terlindungnya data dan informasi dari setiap ancaman yang dapat timbul.
\end{abstract}

Kata kunci: evaluasi, sistem informasi penjualan kredit

\section{PENDAHULUAN}

Ketatnya persaingan antar perusahaan mendorong setiap perusahaan untuk memiliki perencanaan dan strategi dalam menjalankan kegiatan usahanya. Perusahaan sangat memerlukan adanya karyawan yang dapat bekerja efektif, efisien, dan ekonomis. Dalam menjalankan fungsi manajemen, diperlukan adanya informasi pendukung yang relevan dan akurat untuk pengambilan keputusan. Selain itu, juga berguna untuk penyusunan perencanaan strategi bisnis perusahaan serta pengendalian kegiatan perusahaan secara efektif dan efisien dalam mencapai tujuannya. Untuk itu diperlukan suatu sistem informasi yang dapat menjawab kebutuhan dan mengatasi masalah yang timbul. Dengan memiliki sistem informasi yang baik dan handal, tentunya akan menghasilkan informasi yang berkualitas.

Tujuan berdirinya suatu perusahaan adalah untuk memperoleh laba yang optimum dalam jangka panjang melalui barang atau jasa yang dihasilkan dan dipasarkan sehingga dapat dipertahankan eksistensinya dalam masyarakat. Oleh karena itu, pemimpin perusahaan harus mampu membawa perusahaan menjadi efisien dan efektif atau dengan kata lain menekan faktor yang menghambat perusahaan untuk mencapai tujuannya.

Sistem informasi dalam suatu organisasi perusahaan sangatlah penting untuk menunjang tercapainya tujuan perusahaan. Dalam hal ini, jika sistem informasi penjualan tidak efektif, maka hal tersebut akan berakibat fatal bagi perkembangan perusahaan. Penjualan merupakan aktivitas yang penting bagi perusahaan. Dengan penjualan, perusahaan dapat menghasilkan laba untuk membiayai kelangsungan usaha perusahaan dan perkembangannya, maka semua informasi sangatlah penting bagi perusahaan.

PT Arori Jaya adalah perusahaan yang bergerak dalam bidang penjualan alat-alat kebutuhan kantoran dan juga menyediakan perbaikan/reparasi. Untuk menunjang kegiatan perusahaan, diperlukan sistem informasi yang memadai agar penjualan barang-barang sesuai dengan yang diinginkan perusahaan.

Manajemen audit merupakan suatu aktivitas pemeriksaan yang mengevaluasi kegiatan operasional perusahaan dan digunakan untuk mengetahui apakah kegiatan operasional perusahaan sudah berjalan efektif, efisien, dan ekonomis. Oleh karena itu, perlu dilakukan evaluasi secara berkala guna memastikan keandalan sistem informasi agar tetap terjaga atau bahkan ditingkatkan. Pentingnya manajemen audit dalam dunia usaha serta pentingnya peranan fungsi penjualan pada perusahaan, maka diambil keputusan untuk memilih bidang ini dalam penelitian yang berjudul "Evaluasi Sistem Informasi Penjualan Pada PT Arori Jaya".

Karena luasnya sistem informasi yang diterapkan dalam sebuah perusahaan, maka perlu dilakukan pembatasan ruang lingkup penelitian, yaitu pada sistem informasi penjualan yang sedang berjalan yang dilakukan oleh perusahaan. Ruang lingkup yang akan dibahas, yaitu sistem informasi penjualan kredit, mulai dari melakukan penawaran sampai dengan 
pembuatan laporan penjualan; tidak membahas mengenai klaim garansi dan sistem retur, hanya sampai pada sistem pembayaran kredit; metode audit yang digunakan adalah audit around the computer dengan pengendalian terhadap prosedur pelaksanaan dan sistem informasi yang terdiri dari pengendalian manajemen yang merupakan pengendalian keamanan dan pengendalian operasional, pengendalian aplikasi yang merupakan pengendalian boundary, pengendalian input, dan pengendalian output.

\section{METODE PENELITIAN}

Metode yang digunakan dalam penelitian ini untuk mendapatkan data yang lengkap dan akurat serta tujuan dan manfaat yang diinginkan, yaitu studi kepustakaan, studi lapangan (melalui wawancara, check list, observasi, dan studi dokumentasi.

\section{HASIL DAN PEMBAHASAN}

berdasarkan pengumpulan data, diperoleh informasi bahwa fungsi yang terkait dengan kegiatan penjualan antara lain bagian marketing, inventory control/gudang, finance, accounting, dan dealer sales manager. Dokumen yang digunakan dalam kegiatan penjualan antara lain formulir Quotation (dokumen ini dikeluarkan oleh bagian marketing pada saat barang sudah siap dijual), Sales Order (dokumen ini dikeluarkan oleh bagian marketing pada saat customer memberikan Purchase Order), invoice (dokumen ini dikeluarkan oleh Dealer Div.Sales Manager pada saat bagian marketing memberikan PO), Delivery Order (dokumen ini dikeluarkan oleh bagian Inventory Contol pada saat barang sudah siap untuk dikirim kepada customer).

Prosedur bisnis yang sedang berjalan dalam perusahaan adalah (1) Bagian menawarkan barang (proses pada bagian ini dimulai ketika bagian marketing melakukan penawaran barang kepada customer. Bagian marketing menawarkan barang beserta list dan harga sehingga customer mengetahui barang apa saja yang dijual oleh bagian marketing dan mengetahui harga barang tersebut. Kemudian, bagian marketing harus mengetahui update harga barang apabila terjadi perubahan harga sewaktu-waktu sehingga mempermudah customer dalam mengetahui harga barang tersebut); (2) Bagian membuat sales order (proses pada bagian ini dilakukan setelah bagian marketing mendapatkan Purchase Order (PO) dari customer, kemudian bagian marketing membuat Sales Order (SO) berdasarkan PO dari customer. Setelah itu, bagian marketing meminta persetujuan dari Dealer Division Sales Manager; (3) Bagian membuat invoice (proses pada bagian ini merupakan proses lanjutan dari adanya SO dari bagian marketing, kemudian Dealer Division Sales Manager membuat invoice dan memberikan SO, PO, dan invoice kepada Inventory Control); (4) Bagian membuat Delivery Order (proses pada bagian ini merupakan proses lanjutan dari adanya SO yang sudah disetujui dan invoice yang sudah dibuat oleh Dealer Division Sales Manager, bagian gudang kemudian membuat Delivery Order sesuai dengan invoice yang ada serta menyerahkan barang kepada driver); (5) Bagian mengirim barang (proses ini adalah proses lanjutan dari adanya barang, SO, invoice, dan DO yang sudah disiapkan, kemudian mengirim barang beserta dokumen yang ada. Setelah itu, meminta otorisasi dari customer dan menyerahkan dokumen-dokumen tersebut kepada bagian finance); (6) Bagian pencatatan piutang (bagian ini adalah bagian lanjutan dari adanya dokumen yang diserahkan oleh driver, kemudian bagian finance mencatat piutang dan menyerahkan dokumen-dokumen kepada bagian accounting); (7) Bagian pembuatan laporan (setelah menerima invoice dan SO dari bagian finance, bagian akuntansi memasukkan penjualan tersebut ke dalam buku besar dan membuatkan laporan berkala kepada manajer/direksi, kemudian manajer/ direksi menandatangani laporan berkala tersebut).
Sistem yang berjalan dalam perusahaan menggunakan aplikasi MyERP Plus. Aplikasi ini dirancang oleh IT Consultant perusahaan, dengan bantuan perusahaan pembuat software yaitu mybs. Bahasa pemrograman dari aplikasi ini menggunakan Visual Basic, dengan database My SQL. Dengan adanya palikasi ini, diharapkan dapat membantu proses pencatatan yang terkomputerisasi sehingga dapat mendukung proses penjualan secara keseluruhan.

Temuan dan rekomendasi untuk pengendalian manajemen keamanan meliputi hal-hal seperti (1) Perusahaan tidak memiliki alarm kebakaran otomatis, maka sebaiknya perusahaan menggunakan alarm kebakaran otomatis; (2) Tidak ada nomor purchase order dari customer pada Delivery Order dan invoice, maka sebaiknya perusahaan menyisipkan nomor Purchase Order pada Delivery Order dan invoice; (3) Tidak ada tangga dan pintu darurat, maka sebaiknya perusahaan menggunakan alat pendeteksi kebakaran atau perubahan struktur bangunan sehingga dapat mengurangi terjadinya kehilangan aset; (4) Dokumen penjualan dapat dicetak oleh bagian yang tidak bersangkutan, maka sebaiknya perusahaan memberikan batasan akses kepada setiap bagian agar mencegah terjadinya kecurangan dalam input dan output data; (5) Perusahaan tidak memiliki bukti tertulis saat driver menerima barang dari gudang, maka sebaiknya perusahaan membuat bukti tertulis terhadap penyerahan barang saat diserahkan ke driver; dan 6) Bagian penagihan melakukan secara manual terhadap piutang yang jatuh tempo pada invoice, maka sebaiknya perusahaan memiliki sistem otomatis yang dapat menampilkan invoice yang jatuh tempo setiap harinya.

Temuan dan rekomendasi untuk pengendalian manajemen operasional meliputi hal-hal seperti (1) Tidak memiliki help desk, maka sebaiknya terdapat prosedur secara tertulis mengenai cara menggunakan sistem, bagaimana cara mengatasi jika terdapat kesalahan dalam pengoperasian tersebut; (2) Sistem tidak digunakan secara optimal, maka sebaiknya perusahaan menggunakan sistem secara optimal agar kinerja perusahaan menjadi lebih efisien dan efektif; (3) Karyawan belum menggunakan komputer untuk kegiatan yang seharusnya, maka sebaiknya perusahaan membuat pengendalian batasan akses terhadap karyawan.

Temuan dan rekomendasi pengendalian boundary meliputi hal-hal seperti (1) Pemakai komputer adalah orang yang tidak berwewenang, maka sebaiknya diberikan batasan akses terhadap setiap bagian sehingga mencegah terjadinya kecurangan; (2) Sistem tidak secara otomatis melakukan log off ketika aplikasi tidak digunakan oleh user dalam jangka waktu tertentu, maka sebaiknya perusahaan membuat automatically log off.

Temuan dan rekomendasi untuk pengendalian input meliputi (1) Tampilan input pada aplikasi perusahaan tidak mudah dimengerti oleh user, maka sebaiknya perusahaan melakukan training terhadap karyawan agar lebih mahir menggunakan aplikasi; (2) Pernah terjadi manipulasi dalam peng-inputan data ke dalam aplikasi penjualan perusahaan, maka sebaiknya perusahaan melakukan pengecekan terhadap aplikasi atas peng-inputan data; (3) Peng-inputan data penjualan tidak dilakukan oleh bagian tertentu, maka sebaiknya perusahaan melakukan pemisahan fungsi dan tanggung jawab pada setiap bagian.

Temuan dan rekomendasi untuk pengendalian output meliputi (1) Laporan penjualan dapat dicetak tidak sesuai dengan periode yang ditentukan, maka sebaiknya laporan penjualan yang dihasilkan harus sesuai dengan periode yang ada; (2) Pernah terjadi ketidakcocokan antara input penjualan dan dokumen sumber, maka sebaiknya dokumen yang ada dicek kembali sehingga menghindari terjadinya ketidakcocokan antara input dan dokumen sumber.

\section{SIMPULAN}

Berdasarkan hasil survei dan pengamatan yang dilakukan kepada Sistem Penjualan Kredit pada perusahaan, 
maka dapat disimpulkan sebagai berikut. Pertama, pengendalian manajemen keamanan dikategorikan baik. Hal ini dilihat dari adanya peng-installan anti virus pada komputer yang selalu di-scan dan di-update setiap bulan dan adanya tabung pemadam kebakaran pada setiap lantai. Dari pengendalian yang telah baik ini. Hal ini dibuktikan dengan tidak ditemukannya risiko-risiko yang rentan bagi perusahaan. Namun, perlu adanya aplikasi yang dapat menampilkan invoice yang jatuh tempo agar tidak adanya invoice yang terlewat karena dapat mempengaruhi keuangan perusahaan, sekaligus tidak efektif dan efisien karena harus mencari dokumen yang berhubungan. Kedua, pengendalian manajemen operasional dikategorikan baik. Hal ini dapat dilihat dari adanya memiliki UPS (Uniterrupable Power Supply) sebagai upaya antisipasi perusahaan agar data-data dalam perusahaan tidak hilang ketika terjadi pemadaman listrik secara tiba-tiba. Namun, adapun kelemahan dalam manajemen operasi, yaitu adanya penggunaan komputer perusahaan yang digunakan oleh karyawan untuk kegiatan yang tidak seharusnya. Ketiga, pengendalian boundary dikategorikan baik. Hal ini dapat dilihat dari adanya login dalam pemakaian komputer dengan berdasarkan ID tertentu, misalnya pembatasan akses dengan menggunakan ID dan password. Password yang di-input adalah invisible, yaitu hanya berupa block titik. Akan tetapi, adapun kelemahan dari perusahaan adalah pemakai komputer adalah orang yang tidak berwewenang, disebabkan tidak adanya automatically log off pada sistem sehingga user manapun bebas menggunakan akses komputer tersebut. Update password yang tidak dilakukan secara periodik dapat mempermudahkan orang lain untuk menghafal password tersebut. Keempat, pengendalian input dikategorikan baik. Hal ini dapat dilihat dari adanya sistem dengan aplikasi yang canggih dan memiliki software yang baik bagi perusahaan. Dari pengendalian yang baik itu, masih terdapat kelemahan yaitu pernah terjadi manipulasi dalam peng-inputan data ke dalam aplikasi penjualan sehingga dapat membuat kerugian bagi perusahaan dan juga peng-inputan data penjualan tidak dilakukan oleh bagian tertentu. Kelima, pengendalian output dikategorikan cukup. Hal ini dapat dilihat dari adanya laporan penjualan yang terjadi secara rutin dan diperiksa secara berkala. Akan tetapi, adanya kelemahan-kelemahan seperti ketidakcocokan antara dokumen sumber dengan data-data dalam sistem sehingga membuat missing data bagi perusahaan dan juga sulitnya memahami laporan penjualan sehingga memerlukan penjelasan dari bagian yang terkait.

\section{DAFTAR PUSTAKA}

Anonim. (2002). Kamus Besar Bahasa Indonesia, edisi ketiga, Jakarta: Balai Pustaka.

Arens, A., dan Loebbecke, J.K. (2003). Auditing pendekatan terpadu buku satu, edisi Indonesia. Diterjemahkan oleh Jusuf, Amir A, Jakarta: Salemba Empat.

Gondodiyoto, S. (2003). Audit sistem informasi: Pendekatan sistem, Jakarta: PT Media Global Edukasi.

Gondodiyoto, S., dan Hendarti, H. (2006). Audit sistem informasi, edisi pertama, Jakarta: Mitra Wacana Media.

Gondodiyoto, S. (2007). Audit sistem informasi dan pendekatan CobIT, edisi revisi, Jakarta: Mitra Wacana Media.

Gondodiyoto, S. (2007). Audit sistem informasi lanjutan plus standar, panduan, prosedur audit SI dari ISACA, edisi pertama, Jakarta: Mitra Wacana Media.

Hall, J.A. (2001). Accounting information system, $3^{\text {rd }}$ ed., New York: Prentice Hall.

Frederick, L.J., and Dasaratha, V.R. (2003). Accounting information systems, Canada: Thomson South - Western.

Frederick, L.J., and Dasaratha, V.R. (2008). Accounting information systems, Canada: Thomson South - Western.

McLeod, R. et al. (2001). Management information system, $8^{\text {th }}$ ed., New Jersey: Prentice Hall.

Mulyadi. (2001). Sistem informasi, $3^{\text {rd }}$ ed., Jakarta: Salemba Empat.
O' Brien, J.A. (2001). Introduction to infomation system: Essential for the internetworked e-business enterprise, edisi kesepuluh, McGraw-Hill.

O' Brien, J.A. (2005). Introduction to infomation system, $12^{\text {th }}$ ed., New York: McGraw-Hill.

Pickett, K.H. Spencer. (2005). The essensial handbook of internal auditing, West Sussex, England: John Wiley \& Sons.

Turban E., K. Rainer, and R.E. Potter (2003). Introduction to information technology, 2nd ed. WileyWeber, R. (1999). Information system control and audit, New Jersey: Prentice Hall, Inc.

Whitten, J., Bentley, L.D., and Dittman, K.C. (2004). Systems analysis and design methods, edisi keenam, United States of America: McGraw-Hill.

Williams, B., and Sawyer, S. (2005). Using information technology: A practical introduction to computer and communication, McGraw-Hill. 